\title{
Pre-Service Teachers' Skills in Analyzing the Mathematics Competency Based on Bloom Taxonomy
}

\author{
Vita Istihapsari, Afit Istiandaru, Siti Nur Rohmah \\ Universitas Ahmad Dahlan, Jl. Ahmad Yani, Tamanan, Banguntapan, Bantul, 55191 DIY Indonesia \\ e-mail: vita.istihapsari@pmat.uad.ac.id
}

\begin{abstract}
Professional teachers need to be skilled in planning their lesson. One of the activities to plan the lesson is analyzing the competence and teaching material demanded by the curriculum. This article aims to describe the Indonesian pre-service mathematics teachers' skills in analyzing junior high school mathematics competence. The analysis is important to prepare the appropriate material for their students. This is qualitative research involving 26 pre-service teachers enrolled in the subject of Curriculum Analysis for Junior High School. First, they were assigned to analyze a given basic competence and were then challenged to select the appropriate materials and the indicators when the competence achieved according to Bloom taxonomy. Surprisingly, though there are many reference books available for sources of analysis, the teacher candidates found some difficulties in arranging the topics and composing the appropriate indicators. Some errors found such as the use of unmeasurable verbs, unclear activities, and illogical-irrelevant topics.
\end{abstract}

Keywords: Bloom taxonomy, Competence achievement indicator, Curriculum analysis, Junior high school, Pre-service teacher, Professional teacher, School mathematics.

How to Cite: Istihapsari, V., Istiandaru, A., \& Rohmah, S. N. (2019). Pre-Service Teachers' Skills in Analyzing the Mathematics Competency Based on Bloom Taxonomy. International Journal on Emerging Mathematics Education, 3(2), 117-128. http://dx.doi.org/10.12928/ijeme.v3i2.14549

\section{INTRODUCTION}

The government of Indonesia set some indicators of professionalism for teachers. Mastering subject knowledge and teaching methodology are two among them (Thair \& Treagust, 2003; Sari, 2012). This paper is concerned with how the preservice mathematics teachers master the subject knowledge and, moreover, how they prepare their materials in a systematical way.

According to the regulation of the Indonesian Ministry of Education and Culture number 24/2016, the material selected for teaching must be derived from certain basic competencies (MOEC, 2016). As suggested by the curriculum, the learning process has to facilitate the students to achieve competence at the end of the learning process. Therefore, a professional teacher needs to be able to analyze the demand of the curriculum as articulated in the basic competences. In a simpler way, the teacher needs to know what the students are expected to achieve before planning the material, method, and assessment (Courey et al., 2013).

Mathematics teachers need to understand the material they have to teach, the depth of the knowledge, the scope of the material, and also their relevance to the psychological development of their students (Zazkis, Liljedahl, \& Sinclair, 2009). This understanding is part of the steps in planning a good mathematics lesson. Teaching the inappropriate material will prevent the students from achieving curriculum demands. It could also happen if the material is too easy or too difficult. 
In the current curriculum implemented in Indonesia, the basic competencies were constructed according to the Bloom taxonomy. They contain certain verb(s) which represent the level of cognitive skill the students need to perform. Bloom taxonomy has six levels of cognitive performance. It starts with remembering, understanding, applying, analyzing, evaluating, and creating (Forehand, 2010). The first three levels are categorized as the lower order thinking skills, while the next three levels belong to the higher-order thinking skills, as illustrated in Figure 1. As it constructs the basic competences, the verb sets the minimum behavior or skills which the students need to achieve at the end of the learning.

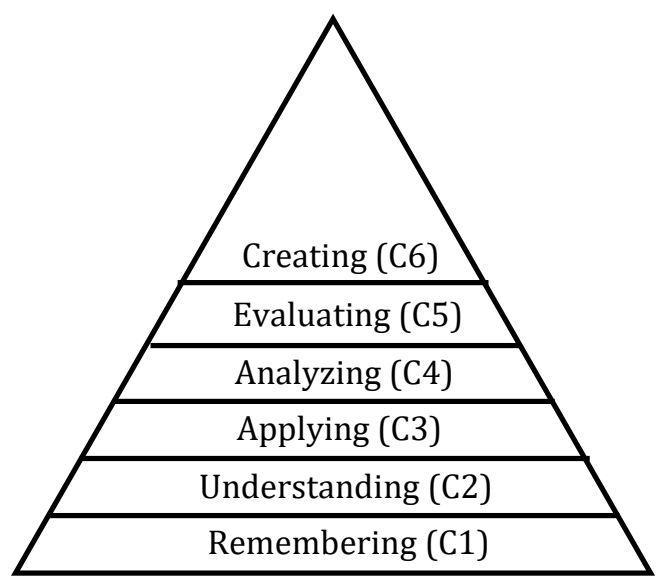

Figure 1. The Bloom Taxonomy

In the lesson, teachers need to facilitate their students to experience sets of learning activities starting from the simplest one to the level of basic competence. For instance, if the basic competence uses the verb of "analyzing', then the teacher needs to arrange the learning activities which enable the students to gradually reach the analysis level. It could start from the lowest level (remembering), and then step by step develops into understanding the concept, using the concept, and then finally analyzing the concept. Thus, the minimum competence will be successfully achieved.

The gradual development of the learning activities accommodates the development of students' cognition. Students cannot directly jump to understand certain material without experiencing the pre-requisite one. According to Piaget, students have an existing scheme of knowledge. Learning provides a process of assimilation and accommodation which enable the students to construct a new scheme (Netti \& Nusantara, 2016). Thus, the learning material needs to be arranged from the simplest to the most complex, and so does the learning activities.

What happens in Indonesia currently has not yet been ideal. Through experiences we have dealing with the teachers, we found that many teachers apply the wrong practice regarding the lesson planning. As there are many reference books on the market, they use the book as the guidance of learning. They follow every step of the book without analysis if it suits or not, the basic competence or even their students' cognitive development. Some books provide the analysis of material such as the competence achievement indicators, but many more don't.

There has not yet been a specific publication about the pre-service teachers' skills in analyzing the material given to students in Indonesia according to the 2013 Curriculum. Though we believe that the assessment about teaching skills has been mostly done through the professional development program (Thair \& Treagust, 2003;

IJEME, Vol. 3, No. 2, September 2019, 117-128. 
Sari, 2012), usually designed for in-service teachers and the report was not publicly accessible. This article aims to describe Indonesian pre-service mathematics teachers' skills in analyzing junior high school mathematics competence.

\section{RESEARCH METHOD \\ Research design and stages}

This research is qualitative research. First, we developed a task to analyze a mathematics basic competence from junior high school level. The task was designed to test the ability of pre-service teachers in selecting the appropriate materials, and constructing the appropriate indicators and learning objectives. All of the components represent the ability to plan a mathematics learning lesson.

Second, we delivered seven workshop to analyze the mathematics competences and materials. The details of the workshop agenda are: (1) Introduction to curriculum analysis and the document products; (2) Analysis of the graduate competence standard; (3) Developing factual, conceptual, procedural, and metacognitive knowledge; (4) Introduction to Bloom taxonomy and analysis of the mathematics basic competences for junior high school; (5) Reviewing and selecting teaching materials related to certain basic competence; (6) Developing the indicators of competence achievement; and (7) Constructing learning objectives

Next, we gave the prepared task to a group of pre-service mathematics teachers and analyzed their work. The analysis was based on the relevancy to the Bloom taxonomy, the adequacy of the material, and the quality of the learning activities.

Finally, among their works, we selected some products which could be followed up by an interview of their understanding and perception of the task.

\section{Participants}

In this research, we involved 26 pre-service mathematics teachers as the participants. They enrolled in the subject of Curriculum Analysis for Junior High School in the second term of 2018/2019 academic year in the Mathematics Education Department of Universitas Ahmad Dahlan, Yogyakarta, Indonesia. They did not have any formal teaching experience. This subject was their first experience engaging with the mathematics curriculum.

\section{Data collection method and instrument}

The data in this research was the results of the pre-service teachers' work in analyzing the basic competences, developing the achievement indicators, and the selected relevant topics. The data were collected through test and interview.

The test instrument is a single task written in Bahasa Indonesia as illustrated in Figure 2. 
Lakukan analisis materi pada KD berikut dengan menggunakan format yang disediakan! [C4; Skor: 100].

Kelas VII

KD 3.10. Menganalisis hubungan antar sudut sebagai akibat dari dua garis sejajar yang dipotong oleh garis transversal.

KD 4.10. Menyelesaikan masalah yang berkaitan dengan hubungan antar sudut sebagai akibat dari dua garis sejajar yang dipotong oleh garis transversal.

\begin{tabular}{||c|c|c|c|c|}
\hline $\begin{array}{c}\text { KD dan Level } \\
\text { KD }\end{array}$ & $\begin{array}{c}\text { Jenis } \\
\text { Pengetahuan/ } \\
\text { Keterampilan }\end{array}$ & Submateri & $\begin{array}{c}\text { Indikator dan } \\
\text { Level Indikator }\end{array}$ & $\begin{array}{c}\text { Tujuan } \\
\text { Pembelajaran }\end{array}$ \\
\hline & & & & \\
\hline & & & & \\
\hline
\end{tabular}

Figure 2. Material Analysis

Figure 2 illustrates the task with C4 level, namely analysis, based on the Bloom's taxonomy. The maximum score was 100 if the pre-service teachers were successful in doing the task. We asked them to analyze two given basic competences (KD 3.10 and 4.10) in Grade VII of junior high school using the given format.

The KD 3.10 states, "Analyzing the relationship among angles as a result of two parallel lines intersected by a transversal line." According to the Indonesian MOEC regulation number 24/2016, the KD 3.10 belongs to the cognitive domain (MOEC, 2016). Therefore, the participants need to refer to the Bloom's taxonomy to categorize the competence (Forehand, 2010). The level of cognition of this competence is an analysis which categorized as a higher-order thinking skill (Forehand, 2010; Thompson, 2008; Näsström, 2009).

Further, the KD 4.10 states, "Solving problems related to the relationship among angles as a result of two parallel lines intersected by a transversal line." According to the Indonesian MOEC regulation number 24/2016, the KD 4.10 belongs to the psychomotor domain (Dyer, Gregersen, \& Christensen, 2011). Furthermore, the psychomotor domain, in the Indonesian 2013 curriculum, has two categories, namely the mental skills and the concrete skills (Istihapsari et al., 2019). The mental skills refer to the classification of Dyer et al. (2011), while the concrete skills refer to the Dave taxonomy which classifies the skills into five levels, namely (1) imitating, (2) manipulating, (3) accuracy, (4) articulation, and (5) naturalization (Dave, 1975). Mathematics basic competence, in this domain, usually belongs to the mental skills (Istihapsari et al., 2019; Özgelen, 2012).

After classifying the level of basic competence, the pre-service teachers need to determine the factual, conceptual, procedural, and metacognitive knowledge relevant to the competence and write it in the second column (See Figure 2). In the third column, we asked them to select the relevant topics as well.

Furthermore, in column 4, we asked them to set some indicators of when the competence is achieved by students. While in the last column, we asked them to formulate the learning objective(s) according to the learning activities they set at the indicators.

\section{Data analysis}

The data were analyzed qualitatively by observing the results of the test and then confirming the results to the participants. Thus, we used a method triangulation

IJEME, Vol. 3, No. 2, September 2019, 117-128. 
to confirm the validity of the data. From the data analysis, we discussed extensively to draw some conclusions.

\section{RESULTS AND DISCUSSION}

To start the explanation in this section, we present the descriptive result of the pre-service teachers' work. The details were presented in Table 1.

Table 1. Results of the pre-service teacher analysis skills

\begin{tabular}{|c|c|c|c|c|c|}
\hline & $\mathrm{N}$ & Minimum & Maximum & Mean & Std. Deviation \\
\hline $\begin{array}{l}\text { Pre-Service Teacher } \\
\text { Analysis Skills }\end{array}$ & 26 & 35 & 92 & 62.12 & 15.609 \\
\hline Valid N (listwise) & 26 & & & & \\
\hline
\end{tabular}

Table 1 shows that the mean of the gained score was 62.12 of the maximum score of 100. It was not a satisfactory result, but it gives a lot of potential information to dig more since the standard of deviation is 15.6 which means some extreme values may exist. Thus, the value of the mean cannot be the only way to represent the results of the pre-service teachers' work (Wilcox, 2017).

Therefore, we tried to analyze the extreme values, both the highest and the lowest. However, as stated at the beginning of this article, we had an interest in the difficulty experienced by the pre-service teachers in curriculum analysis e.g. classifying basic competence, developing indicators, learning material and objectives, so we tried to focus on the lowest ones as the subjects of a further interview.

The details were presented in Table 2 . In Table 2, there are five subjects with the extreme highest score and also five subjects with the extreme lowest score.

Table 2. Extreme values of the pre-service teacher analysis skills

\begin{tabular}{|c|c|c|c|c|}
\hline & & & Case Number & Value \\
\hline Pre-Service Teacher & Highest & 1 & 14 & 92 \\
\hline \multirow[t]{9}{*}{ Analysis Skills } & & 2 & 13 & 84 \\
\hline & & 3 & 16 & 75 \\
\hline & & 4 & 18 & 75 \\
\hline & & 5 & 25 & 75 \\
\hline & Lowest & 1 & 11 & 35 \\
\hline & & 2 & 20 & 36 \\
\hline & & 3 & 21 & 37 \\
\hline & & 4 & 24 & 41 \\
\hline & & 5 & 6 & 45 \\
\hline
\end{tabular}

Quantitatively, if we assume that score 75 is quite close to 62 (the average), then there were at least two students very good at analyzing the mathematics learning material. On the contrary, there were five students with a bad performance.

We selected Subject 11, 20, and 6 to join a short interview while we also looked at their works. Subject 11 wrote the answer as shown in Figure 3. 


\begin{tabular}{|c|c|c|c|c|}
\hline KD dan level & Jenis Pengelabua? / & Submateri & Indikator dea & Tujuan \\
\hline$K D$ & Keteranapilan & & Level indikator & Pembelajaran \\
\hline \multirow{11}{*}{$\begin{array}{l}\text { Menganalisss } \\
\left(E_{A}\right)\end{array}$} & Pengetatiuan: & - Hubungan & - Merrahami hubu- & Sisuoa dayat \\
\hline & Fakfual, Konseptual. & antar sucut & ngun atar sudue (c) & then gratisis hitourge \\
\hline & Prosedural Metakeg - & - Gans sejajar & - Memahami dua & antar suduc padalkenidu- \\
\hline & nitif & - Ganstransver & garis yarqugajar & pan sehori hari \\
\hline & & cal & - Memaharaigars & \\
\hline & & - Perpotongencars & transversal & \\
\hline & & & Memahami perpoto- & \\
\hline & & & negan gans & \\
\hline & & & - Mengaralias huburasen & \\
\hline & & & antar youbur akibaiperano & \\
\hline & & & 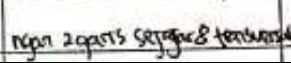 & \\
\hline
\end{tabular}

Figure 3. Subject 11's work.

Subject 11 worked on KD 3.10. In the first column, Subject 11 was good at classifying the $\mathrm{KD}$ at the level $\mathrm{C} 4$ based on the Bloom taxonomy, but failed to explain why all kinds of knowledge (factual, conceptual, procedural, and metacognitive) were relevant to the competence in column 2 , failed to specify clearly the topics which should be discussed in column 3 , used the incorrect verb in column 4 , and set an unclear learning objective in column 5 .

In column 3, Subject 11 wrote that the relevant topics are the relationship among angles, parallel line, transversal line, and intersecting line. When we confirmed through the interview, clearly, Subject 11 had forgoten about the material and had no idea about what kind of topics relevant to this competence. Furthermore, Subject 11 did not review any sourcebook to determine an answer. Thus, Subject 11 just wrote the keywords of the competence and assumed that the material would be exactly related literally to the keywords. Flevares \& Schiff (2014) stated that teachers, especially in their training (both pre-service and in-service), need to review their sourcebook to make sure the concepts listed are correct to teach to their students. Furthermore, a combination of lack of training and limited curricular material could result in the students' misconception (Clements et al., 1999).

Next, Subject 11 developed the indicators by using unmeasurable verbunderstanding. Subject 11 thought that the proof of students achieving competence is when they understand the topics. The use of the "understanding" verb cannot be measured, either by using test or observation. Felder \& Brent (2003) stated that learning objectives need to be formulated using measurable verbs and the teacher has to avoid the use of unmeasurable verbs such as "know", "understand", or "appreciate."

Now, take a look at Subject 20. We provide the work in Figure 4. 


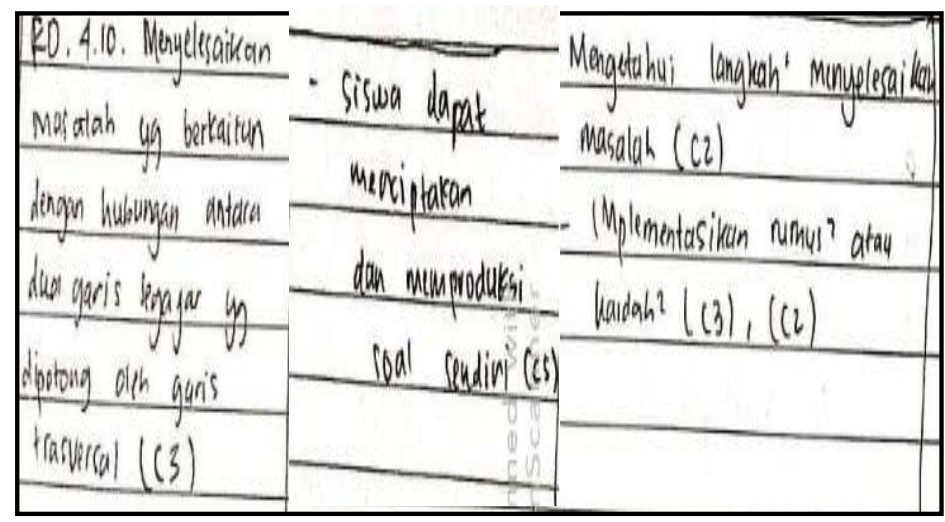

Figure 4. Subject 20's work

Figure 4 presents the work of Subject 20. Subject 20 was good at classifying the level of KD 3.10 as C4 level but failed to classify KD 4.10. KD 4.10 states, "Solving problems related to the relationship among angles as a result of two parallel lines intersected by a transversal line." Subject 3 thought that KD 4.10 is at C3 level. KD 4.10 is, in fact, a psychomotor domain. Thus, it cannot refer to Bloom's taxonomy. According to the MOEC regulation, solving a problem is more appropriate to be referred to Dyer's classification of mental skills.

Further, Subject 20 did not provide clear indicators. We tried to ask for more elaboration, and Subject 20 explained that the formulation of indicators in the learning objective was just to accommodate the sequence of the cognitive level. Subject 20 did not review any reference book and thus it produced unclear learning objectives.

Subject 20 used the verb "knowing" the problem-solving steps, implementing formulas, and producing their own tasks. We can easily assess that "knowing" is an unmeasurable indicator (Felder \& Brent, 2003), while the other two indicators about implementing formulas and producing tasks, Subject 20 admitted that it is unclear since there was no previous review of any reference book.

Here, a reference book is an important part of analyzing competence for preservice teachers. Though the paradigm in planning a teaching process is "follow the plan, not the book," but pre-service teachers need to review many books to have a good foundation in the preparation of the teaching material and selecting the indicators of competency achievement. The common problem of the Indonesian mathematics teachers is lack of planning and they teach just by following the material in the students' book (Pujiono, 2014; Rahayu \& Firmansyah, 2019; Taorina, Chandra, \& Sisworo, 2018). However, it does not mean that teachers leave the book. They need to review many books in order to be able to plan good learning.

Next, we provide the work of Subject 6 as presented in Figure 5. 


\begin{tabular}{|c|c|c|}
\hline Surmater & Indibuter clan & Tuguan \\
\hline & Level lndikentor & Pembelajaran \\
\hline - $J^{e t i j}=J^{\tan i s}$ & - Mangetahai sadus & Pegeno didil mampa \\
\hline sudut & lanup, lodut tuwpel. & mengetaki matam - \\
\hline - Habuengan antara & dan codet silew- & nucaum rama \\
\hline \multirow[t]{14}{*}{ Noo cudut } & siku - (C1) & pudut yang a. \\
\hline & - Munglarkan hukungan & saling Grkubungan. \\
\hline & antar dua sudut & \\
\hline & dan dua gavis & \\
\hline & egejor youg dipoteng & \\
\hline & deh ogavi transversal & \\
\hline & $(c 2)$ & \\
\hline & - Muggetahui cudut din & \\
\hline & butlkrougon, wdur & \\
\hline & 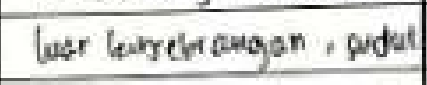 & \\
\hline & talam nphak, Qudut & \\
\hline & luarctphah, wdut & \\
\hline & Gurdol belakeng, dan & \\
\hline & wdut shadap (CI) & \\
\hline
\end{tabular}

Figure 5. Subject 6's work

What we provide in Figure 5 is part of Subject 6's work for the KD 3.10 analysis. We only present column 3 (left), column 4 (middle), and column 5 (right). Subject 6 wrote in column 3 that the relevant topics for this competence are kinds of angle and the relationship between two angles. We asked for elaboration on this selection during the interview. Subject 6 confirmed that kinds of angles is a topic discussing the classification of angles according to its magnitude-acute angle, right angle, and obtuse angle-and its relationship with the other angles. Subject 6 also confirmed that the relationship between two angles includes corresponding angles, opposite angles, alternate interior angles, alternate exterior angles, consecutive interior angles, and consecutive exterior angles. In this part, Subject 6 deserved a full score.

In column 4, Subject 6 formulated the indicators as follows: (1) Knowing the acute angle, obtuse angle, and right angle (C1); (2) Explaining the relationship between two angles produced by two parallel lines intersected by a transversal line (C2); (3) Knowing the alternate interior angle, alternate exterior angle, consecutive interior angle, consecutive exterior angle, opposite angle, and corresponding angle.

According to the adequacy of the material, the topics discussed in the indicators are quite good, though the topic of supplementary angles is not mentioned. However, understanding the relationship between two angles does not end in determining the 
relationship, but also the impact of the relationship towards the magnitude of the angles. Students should also be skilled in determining the magnitude of angles after knowing the relationship between the two angles. For instance, two opposite angles must be congruent, two alternate interior angles must also be congruent, while the sum of two consecutive interior angles must be $180^{\circ}$.

Moreover, the verb selection used is "knowing" and "explaining". Explaining is measurable as we could observe the behavior. For instance, the students give an oral or written explanation. But, knowing is not measurable as we cannot determine when the students know something. Do they know something after seeing it? Or Reading it? Unmeasurable indicator or learning objective could lead to unclear learning activities.

In column 5, Subject 6 wrote a learning objective, "Students could know the name or kind of angles having a certain relationship." Comparing it to the indicators in column 4, this objective could not accommodate all indicators derived from the achievement, as it is only about the name of the related angles.

A good learning objective and clear indicators will guide the teachers to design clear learning activities, too. Regarding the competence stated in KD 3.10, for instance, activities which can lead to a good indicator of the competence achievement need to be formulated step by step. We have to consider two things, the scope of material and the cognitive development (Istihapsari et al., 2019). Since the KD 3.10 demands skill of analyzing the relationship between two angles, then students can start by mentioning the related angles.

Take a look at Figure 6.

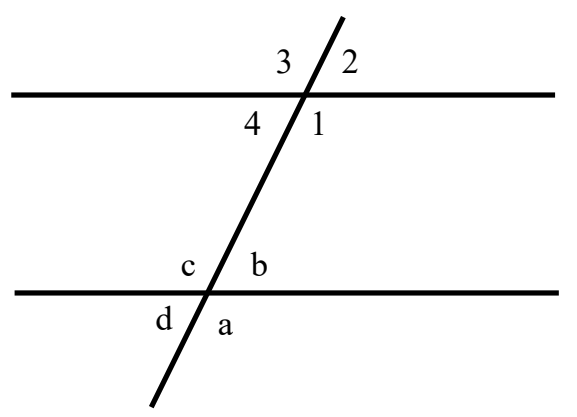

Figure 6. Two parallel lines intersected by a transversal line

Figure 6 presents two parallel lines intersected by a transversal line. In the figure, students can find some angles have a relationship with each other by identifying the similarity or supplementary. Angle 1, 2, 3, 4, a, b, c, and d have different relationships. The students could mention the relation between Angle 1 and 2, 1 and 3, 1 and 4, 1 and b, etc. After that, the teacher could guide the students to determine the magnitude of all of the angles if one of them is given. Thus, the alternative indicators for KD 3.10 are: (1) Identifying the congruent angles and the supplementary angles (C1); (2) Mentioning the relationship among angles (C1); (3) Comparing the magnitude of related angles (C2); (4) Determining the magnitude of the related angles (C3); (5) Finding the formula to find the magnitude of two related angles produced by two parallel lines intersected by a transversal line (C4). The indicators could guide the teachers to plan the learning activities step by step until the competence achieved. 


\section{CONCLUSION}

From the discussion, we address the conclusion on some important points. First, in the Indonesian 2013 curriculum, analyzing basic competences needs to refer to the appropriate taxonomy. The cognitive domain, in the perspective of Indonesian curriculum, could refer to Bloom's taxonomy. Second, pre-service teachers still found difficulty in analyzing mathematics basic competence. The failure can be categorized in three cases, namely (1) the use of the unmeasurable verbs, (2) setting unclear learning indicators, activity, or objectives, and (3) selecting an illogical or irrelevant topic. Third, the cause of the failure was mostly due to the pre-service teacher failing to review various reference books though they were available. A final thought, preservice teachers could be encouraged to do more extensive reading such that they have adequate material to do the competence analysis, especially in mathematics learning.

\section{ACKNOWLEDGMENT}

The authors wish to thank the Directorate of Research and Community Service of the Indonesian Ministry of Research Technology and Higher Education for the research grant under the scheme of Penelitian Dosen Pemula (PDP) in 2018. We would also thank the Institute of Research and Community Service of Universitas Ahmad Dahlan for the grant under the scheme of Penelitian Hibah Bersaing (PHB) in 2019.

\section{REFERENCES}

Clements, D. H., Swaminathan, S., Hannibal, M. A., \& Sarama, J. (1999). Young children's concepts of shape. J. Res. Math. Educ., 30, 192-212.

Courey, S. J., Tappe, P., Siker, J., \& LePage, P. (2013). Improved lesson planning with universal design for learning (UDL). Teacher Education and Special Education, 36(1), 7-27.

Dave, R. H. (1975). Developing and Writing Behavioral Objectives, R. J. Amstrong, ed., California: Educational Innovators Press.

Dyer, J., Gregersen, H., Christensen, C.M. (2011). The innovators' DNA: Mastering the Five Skills of Disruptive Innovators. Boston: Harvard Business School Publishing.

Felder, R. M., \& Brent, R. (2003). Designing and teaching courses to satisfy the ABET engineering criteria. Journal of Engineering Education, 92(1), 7-25.

Flevares, L. M., \& Schiff, J. R. (2014). Learning mathematics in two dimensions: A review and look ahead at teaching and learning early childhood mathematics with children's literature, Frontiers in Psychology, 5, 459.

Forehand, M. (2010). Bloom's taxonomy. Emerging Perspectives on Learning, Teaching, and Technology, 41(4), 47-56.

Özgelen, S. (2012). Students' science process skills within a cognitive domain framework. Eurasia Journal of Mathematics, Science \& Technology Education, $8(4), 283-292$.

MOEC. (2016). Peraturan Menteri Pendidikan dan Kebudayaan RI nomor 24 tahun 2016 tentang Kompetensi Inti dan Kompetensi Dasar pada Jenjang Pendidikan Dasar dan Menengah. Retrieved from: https://jdih.kemdikbud.go.id/arsip/Permendikbud_Tahun2016_Nomor024.zip.

Näsström, G. (2009). Interpretation of standards with Bloom's revised taxonomy: a comparison of teachers and assessment experts. International Journal of Research \& Method in Education, 32(1), 39-51. 
Netti, S. \& Nusantara, T. (2016). The Failure to Construct Proof Based on Assimilation and Accommodation Framework from Piaget. International Education Studies, 9(12), 12-22.

Pujiono, S. (2014). Kesiapan Guru Bahasa Indonesia SMP dalam Implementasi Kurikulum 2013. Litera, 13(2), 250-263.

Rahayu, G. D. S., \& Firmansyah, D. (2019). Pengembangan pembelajaran inovatif berbasis pendampingan bagi guru sekolah dasar. Abdimas Siliwangi, 1(1), 17-25.

Sari, E. S. (2012). Online learning community: a case study of teacher professional development in Indonesia. Intercultural Education, 23(1), 63-72.

Taorina, R. M., Chandra, T. D., \& Sisworo, S. (2018). Pengetahuan Calon Guru Matematika tentang Kurikulum 2013 dalam Penyusunan RPP. Jurnal Pendidikan: Teori, Penelitian, dan Pengembangan, 3(12), 1520-1529.

Thair, M., \& Treagust, D. F. (2003). A brief history of a science teacher professional development initiative in Indonesia and the implications for centralised teacher development. International Journal of Educational Development, 23(2), 201-213.

Thompson, T. (2008). Mathematics teachers' interpretation of higher-order thinking in Bloom's taxonomy. International Electronic Journal of Mathematics Education, 3(2), 96-109.

Wilcox, R. (2017). Modern statistics for the social and behavioral sciences: A practical introduction. London: Chapman and Hall/CRC.

Zazkis, R., Liljedahl, P., \& Sinclair, N. (2009). Lesson plays: Planning teaching versus teaching planning. For the Learning of Mathematics, 29(1), 40-47. 
